NEIGHBOURS

AND NETWORKS 



\title{
NEIGHBOURS AND NETWORKS
}

The Idiom of Kinship in Social Action among the Ndendeuli of Tanzania

\author{
P. H. GULLIVER
}


University of California Press

Berkeley and Los Angeles, California

University of California Press, Ltd.

London, England

Copyright $(\mathrm{C}$ I97 I, by

The Regents of the University of California

Library of Congress Catalog Card Number: 7 I-I I 549I

ISBN: 0-520-01722-6

Printed in the United States of America 